\title{
血液透析患者における上腕骨頚部骨折の治療
}

\author{
社会保険筑豊病院整形外科 \\ 松本 英彦・山口拓 嗣 \\ 井原成男 \\ 社会保険筑豊病院内科 \\ 広重 欣也 \\ 産業医科大学整形外科 \\ 酒井 昭 典 -中 村 利 孝

\section{Intramedullary Fixation with Curved Kirschner Wires for Hemodialized Patients Suffering from Fractures of the Proximal Humerus}

\author{
Hidehiko Matsumoto, Hirotsugu Yamaguchi, and Nario Ihara \\ Department of Orthopaedic Surgery, Chikuho Hospital, Fukuoka, Japan
}

\section{Kinya Hiroshige}

Department of Internal Medicine, Chikuho Hospital, Fukuoka, Japan

\section{Akinori Sakai, and Toshitaka Nakamura}

Department of Orthopaedic Surgery,School of Medicine,

University of Occupational and Enviromental Health, Fukuoka, Japan

\begin{abstract}
Six hemodialized patients suffering from fractures of the proximal humerus were treated surgically with intramedullary curved Kirschner wires. The average of patient age was 78 years (range: 68 to 90). One case was group 2 according to Neer's classification, and five cases were group 3. The method of anesthesia was brachial plexus block in five cases, and local anesthesia in one case with dementia. All patients achieved union of fractures and satisfactory results. This operative procedure, which has less surgical stress and provides sufficient stability for fractures of the proximal humerus, is considered to be very useful for patients with high risks of hemodialysis etc.
\end{abstract}

Key words: fracture of the proximal humerus (上腕骨頚部骨折), hemodialized patient (血液透析患者), curved Kirschner wire (彎曲キルシュナー鋼線), intramedullary fixation（骾内固定）

\section{は じめに}

上腕骨頝部骨折は高齢者に好発する骨折の一つであ るが，高齢者では骨粗鬆性変化が強いため，観血的療 法でも十分な固定力を得ることができず，治療に難渋 することが多い，特に透析患者は手術に際するリスク が高く治療に際して特別な配慮を要する.
当院では高齢者の上腕骨頝部骨折に対しては彎曲 Kirschner 鋼線䯣内固定法（以下，彎曲鋼線䯣内固定 法）を施行し，一定の成果を得ている2.

今回, 我々は血液透析患者で上腕骨近位部骨折を合 併した 6 例に対し，低侵襲で，十分な固定性を得られ る彎曲鋼線䯣内固定法を行い, 良好な術後成績を得た. 結果ならびに注意点を報告する. 
対

象

1994 年 4 月から 2002 年 9 月までの間で上腕骨頝部 骨折を起こした血液透析患者 6 名である。経過観察期 間は $1 \sim 17$ ケ月であった. 内訳は男性 2 例, 女性 4 例，年齢は $68 \sim 90$ 歳，平均 78 歳であった。受傷側は シャント側 4 例, 非シャント側 2 例であった. 受傷ま での血液透析期間は 1 ～120 ケ月（平均 70.6 ケ月）, 骨折型は Neer 分類 Group 2 が 1 例, Group 3 (2 part）が 5 例であった.

方

法

\section{1. 術前準備}

体位は仰臥位とし，手術台の頭側に板を挿入し手術 台を延長させて，頭部を上端に配置した。この状態で X 線透視装置を頭側，患側に設置することで，正面 と軸写両方を術中に透視できるようにした（図 1).

2 . 麻酔

麻酔は腕神経叢ブロック 5 例 ${ }^{9)}$, 局所麻酔 1 例であつ
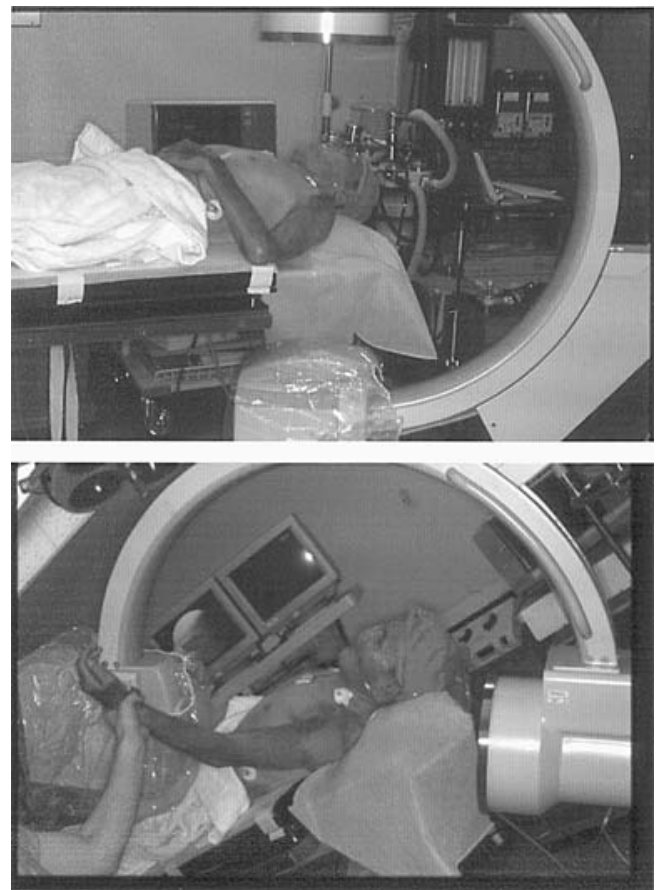

図 1 手術台の頭側に板を挿入し手術台を延長させ, 頭部を上端に配置することで術中に正面・軸写 を容易に確認する事が可能
た。使用する麻酔薬は $0.25 \%$ マーカイン ${ }^{\circledR} 15 \mathrm{ml}$ と $1 \%$ キシロカイン ${ }^{\circledR} 15 \mathrm{ml}$ を混合し, 計 $30 \mathrm{ml}$ を使用し た.また皮切部位および骨折部位にもエピネフリン入 りの $1 \%$ \%シロカインを使用した.

3 . 手術手技

皮切を加える前に整復肢位を確認するため, $\mathrm{X}$ 線 透視下に徒手整復操作を行う。通常は軽度外転・外旋 下での牽引操作を行うことで整復可能である.

皮切および Kirschner 鋼線の挿入部は小川らの方 法に準じた (図 $2 \mathrm{~A}$ )。三角筋粗面部に $6 \sim 7 \mathrm{~cm}$ の縦

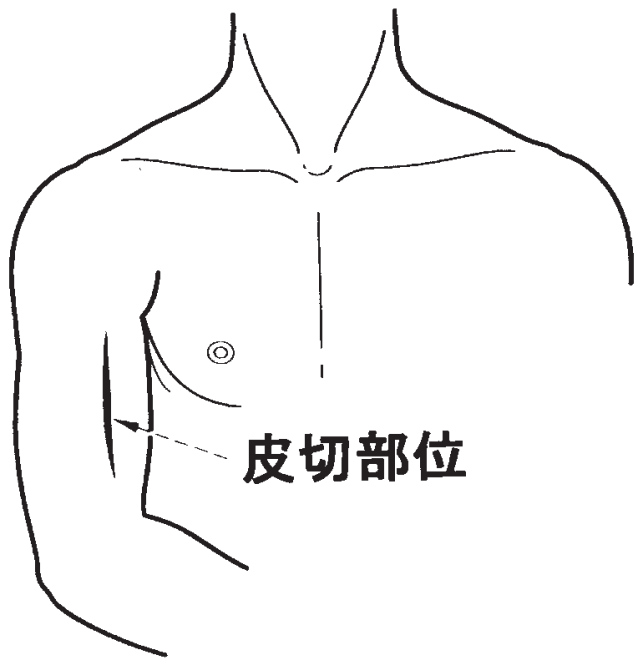

A

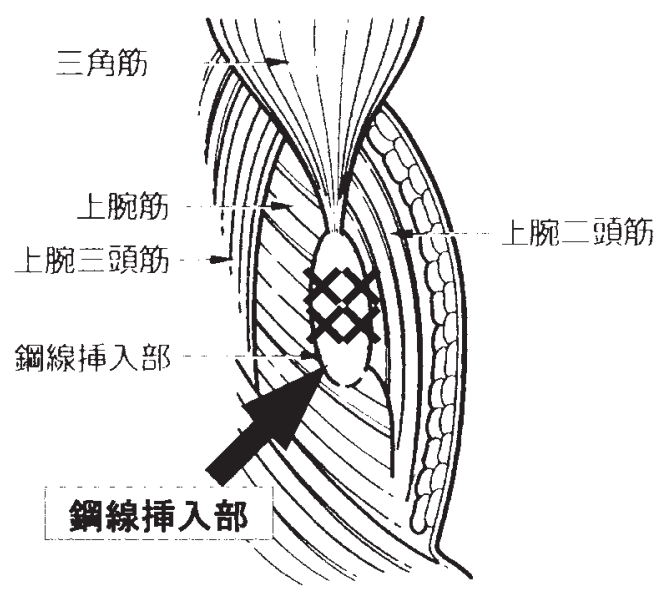

B

図 2 A. 皮切部位.

B. 骨孔作成部位. 
切開を加え骨膜を剥離し，刺入部の骨皮質に径 $3.0 \mathrm{~mm}$ のドリルにて上腕骨の長軸に沿うように可及 的に斜めに開空を行う. Kirschner 鋼線の挿入本数は 当院では 4 本を原則としており, 骨孔は遠位に 2 ケ所, 近位に 2 ケ所, 菱形を描くように作成した（図 $2 \mathrm{~B}$ ).

径 2.3mm Kirschner 鋼線を使用し，骨孔周囲の縦 割れを防ぐため, 遠位の骨孔より順に挿入する，骨折 部に Kirschner 鋼線の先端が達すると再度整復操作 を行い, Ender 釘把持器にて保持し徒手的に可及的 に挿入した後, $\mathrm{X}$ 線透視下に Kirschner 鋼線の近位 端部の方向をコントロールしながらナイロンハンマー で吒いて挿入した。十分な固定性を獲得するため Kirschner 鋼線の刺入方向は最低でも内外側 1 本ずつ 挿入できるように心がけた. Kirschner 鋼線に対し我々 は独自に細工を施した。単純に 1 つの平面状に弧状ま たは $\mathrm{S}$ 字状に彎曲させるのと異なり, 使用する鋼線 の 4 〜 ケ所でそれぞれ違つた方向に 3 次元的に彎曲 を加えた（図 3).これにより挿入した Kirschner 鋼 線同士が髄内で絡み合うことで固定力が増す。骨粗鬆
症の強い症例では髄腔内が広くなつているため彎曲を 強めて対処する。しかし Kirschner 鋼線の打ち込み の際には強く吒きすぎて骨孔部の縦割れを生じさせな いよう，注意を要する。術前に長さの異なる彎曲 Kirschner 鋼線を作成しておくと手術時間を短縮でき る.

また鋼線の末梢端に彎曲を加えることで, Ender 釘把持器による Kirschner 鋼線近位端のコントロー ルが可能となり，また骨頭穿通の予防や上腕部の腫脹 が消退したときの鋼線の皮下への突出の予防などを期 待した（図 4).

4. 後療法

初期の頃, 術後 3 週間の三角巾とバストバンドによ る内施位固定を行っていたが, 内旋位の肢位は整復操 作と逆行しているため, 最近では三角巾は使用せず, 时伸展位でバストバンド固定のみとしている，骨折が シャント側である症例では透析に支障とならない利点 もある. 固定除去後 Codman 体操, 他動的可動域訓 練を始め, 仮骨形成を確認してから積極的な自動・他

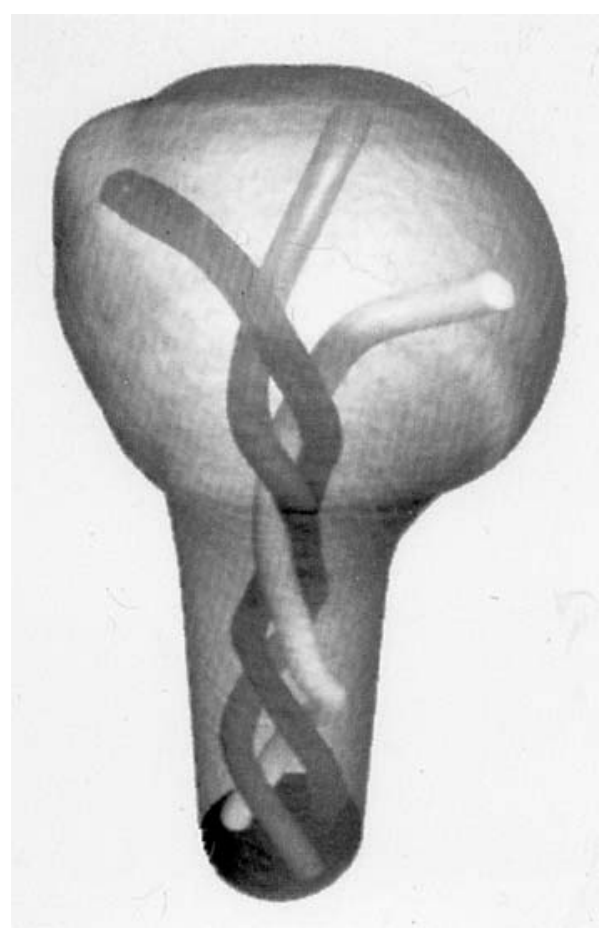

図 3 イメージ図。骨幹部で Kirschner 鋼線同士が絡 み合って髄腔内を占拠することで骨頭穿通・遠 位への滑脱を予防できる. 


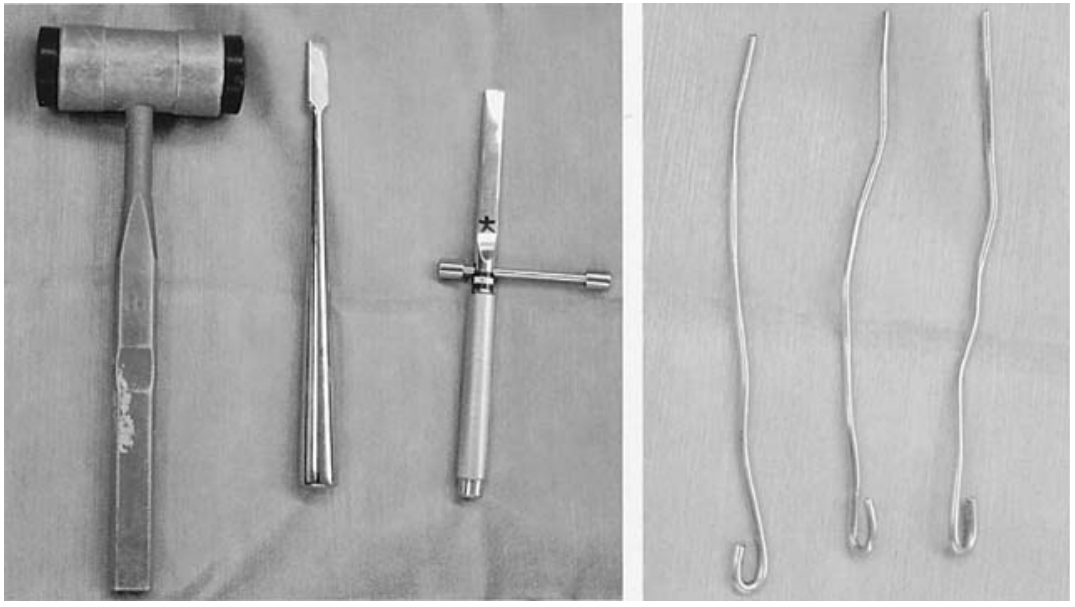

図 4 打ち込む際にはエンダー釘打ち込み器とナイロンハンマーを使用.

動運動を開始した。

またシャント側の骨折例では手術前後 1 回の透析は シャントを使用せず別部位から穿刺を行っている。 ま た手術前後 1 回の透析時には, ヘパリン ${ }^{\circledR}$ の使用を中 止して，フサン ${ }^{\circledR}$ を使用して，出血傾向の改善に努め ている.

\section{結果}

手術時間は 40～75 分 (平均 59.8 分), 術中出血は 20〜 70ml（平均 30ml）であつた. 全例で術後, 疼痛・ 腫脹の著明な改善が見られた。全例とも術後 $3 \sim 6$ 週 で仮骨が出現し，術後約 1 ケ月に脳梗塞の再発にて死 亡した 1 例を除く 5 例で良好な骨癒合を確認した。 1 例に術後 1 週の時点で Kirschner 鋼線の遠位への約 1 センチの滑脱が見られたがそれ以上の進行は無く刺入 部疼痛も認めなかつたため, プロトコル通り運動療法 を行い経過も良好である.

\section{代 表 症 例}

（症例 1）81 歳男性

基礎疾患として透析歴 9 ケ月の慢性腎不全があり, その他慢性 $\mathrm{C}$ 型肝炎による肝硬変, 糖尿病を合併し ていた. 2002 年 9 月自宅玄関にてめまいを起こして 転倒し，左肩を強打した。骨折型は Neer 分類 Group 3 （2 part）であった（図 5A，B）。全身状態を考慮 すると保存的療法も適応と思われたが, 疼痛が強く, 患肢は血液透析のシャント側であり血液透析を維持す
るためにある程度の固定が必要と判断し，受傷後 3 日 目に腕神経叢ブロック下に彎曲鋼線髄内固定法を施行 した（図 5C)。術後 3 週間バストバンドによる中間位 での体幹固定を行い, 固定除去後 Codman 体操を開 始した。術後 4 週で X 線上仮骨を確認し，自動運動 を許可した。術後 4 ケ月の時点で前方挙上は卧位で 150 度, 坐位で 90 度と良好であり, 結帯動作, 結髪 動作が可能であった（図 5D, E).

（症例 2）90 歳女性

基礎疾患として透析歴 8 ケ月の慢性腎不全があり, その他慢性 C 型肝炎による肝硬変, 糖尿病, 狭心症 を合併していた。 2002 年 9 月自宅玄関先で段差につ まづき右手をつき転倒受傷．受傷側はシャント側であつ た. 骨折型は Neer 分類 Group 2 (anatomical neck fracture）であった（図 6A，B）。単純 X 線写真上, 骨折部は粉砕し大結節部にまで骨折が及んでいた。受 傷後 7 日目に腕神経叢ブロック下に彎曲鋼線髄内固定 法を行った．術前の透視下徒手整復では大部分の症例 は軽度外転・外旋位にて整復が可能であるが，本症例 では徒手整復が困難でゼロポジションに近い肢位をと り，骨折部を前方から圧迫する事で整復位が得られる 事を確認した。手術時は骨折部近傍まで Kirschner 鋼線の先端が到達したら術前の整復肢位をとりその肢 位で 4 本の径 $2.3 \mathrm{~mm}$ Kirschner 鋼線を挿入した（図 6C).

術後 3 週間バストバンドによる中間位での体幹固定 を行い，固定除去後 Codman 体操を開始した。術後 4 
図 5 症例 $1: 81$ 歳男性

A. 受傷時内旋位.

B. 受傷時外旋位.

C. 術直後.

D. 術後 4 ケ月.

E. 術後 4 个月. 前方挙上.

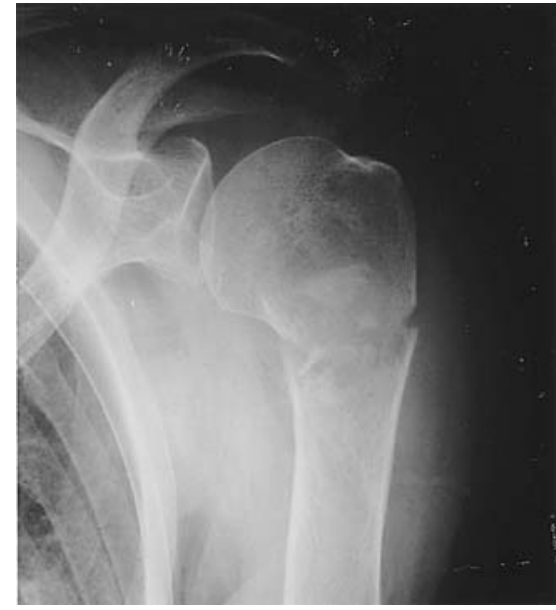

B

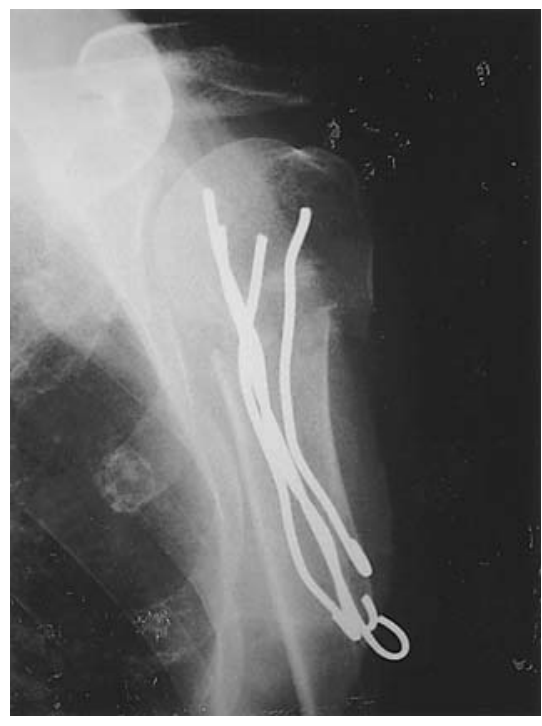

D

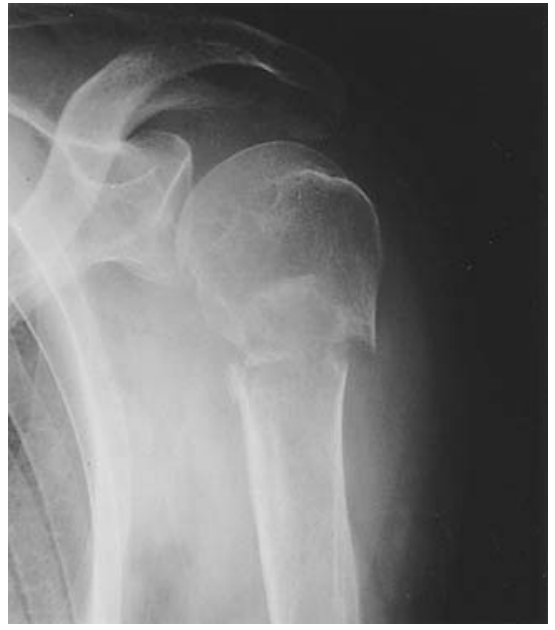

A

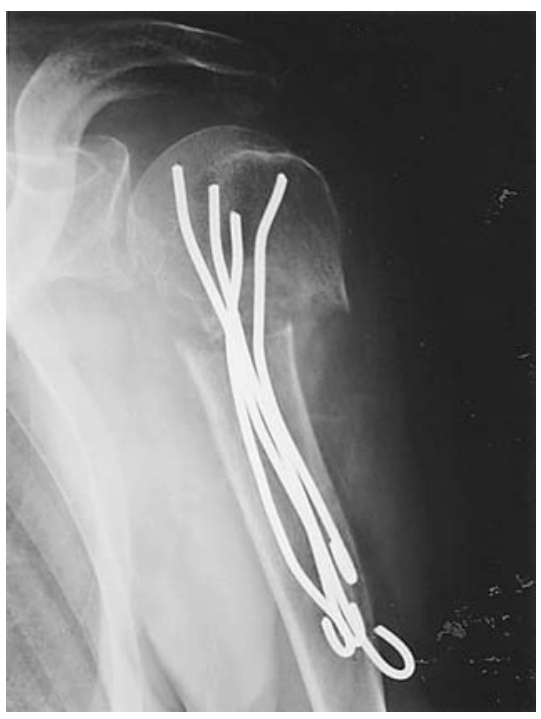

C

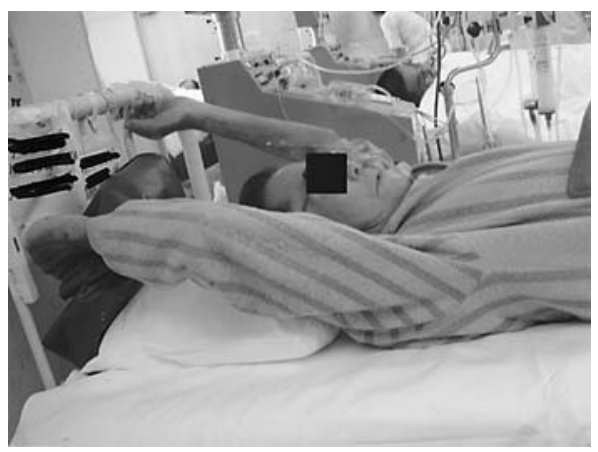

E 
図 6 症例 2:90 歳女性

A. 受傷時. 正面像.

B. 受傷時. 斜位像.

C. 術直後.

D. 術後 4 ケ月.

E. 術後 4 ケ月. 前方挙上.

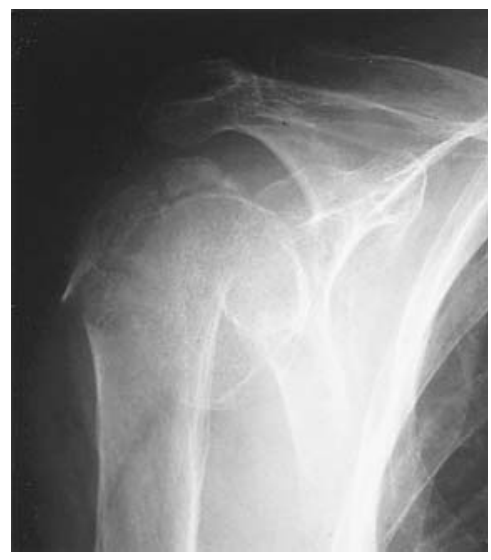

B

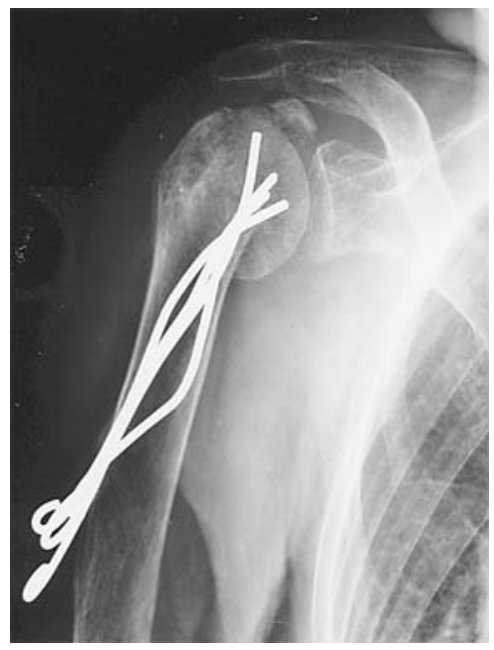

D

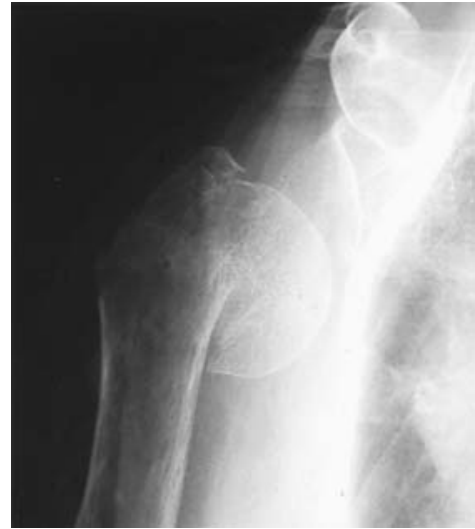

A

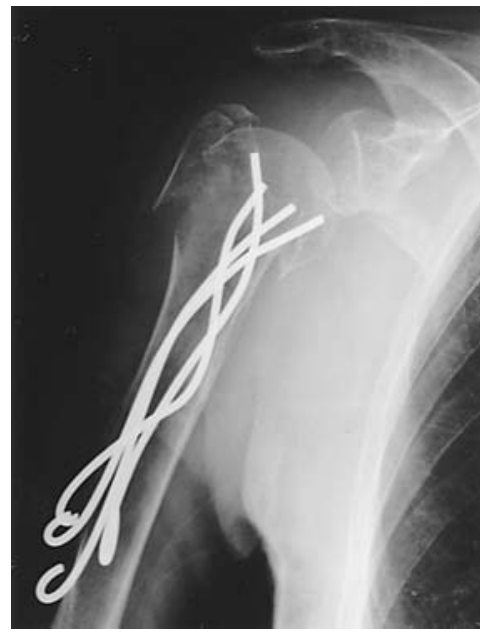

C

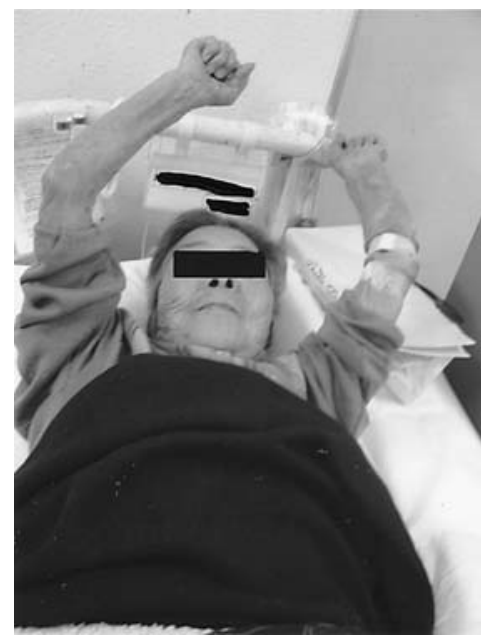

E 
週で X 線上仮骨を確認し, 自動運動を許可した.

術後 4 週で仮骨の出現を確認した. 術後 4 ケ月の時 点で X 線上骨癒合は得られており, 可動域は前方挙 上が臥位で 120 度, 坐位で 80 度と良好であり, 疼痛 も少なく結髪・結帯動作が可能であった（図 6D, E).

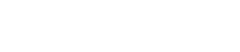

上腕骨頚部骨折は肩関節が非荷重関節であり, $\mathrm{ADL}$ を制限することが少なく，そのため活動性の低 下などから生じる生命予後の悪化の影響はないと考え られがちである。実際，体幹固定法・牽引療法等は一 定の評価を得ている ${ }^{1)}$.

しかし報告によると上腕骨頚部骨折の 1 年以内の死 亡率は $12 \%$ と高率であり, これは大腿骨頚部骨折の 生命予後とほぼ同じである4).また市村らによると上 腕骨近位部骨折の予後因子としては性別・歩行能力・ 年齢に相関があった ${ }^{3)}$ ということからも，大腿骨頝部 骨折と同様, 手術を行い早期除痛・早期離床を促し, $\mathrm{ADL}$ を維持することが生命予後を改善すると思われ る.

血液透析患者の問題点であるが，骨自体の特性とし ては腎性骨異栄養症による骨粗鬆症の進行，また長期 透析の合併症としてアミロイドやアルミニウム沈着に よる骨化障害などが挙げられる. 同年齢の患者よりも 骨脆弱性は進行していると考えられる.

全身性の特性としては抗凝固剂使用による易出血性 と細胞性免疫の低下や白血球貪食能の低下による易感 染性が挙げられる. その他，透析治療に時間を要する ため, 十分な後療法を行う時間を確保しにくい. また 尿毒症，低栄養，貧血，代謝の低下などにより創治癒 の遷延も予想される ${ }^{8)}$. つまり血液透析患者は局所的 にも全身的にもリスクの高い患者であるため，低侵襲 かつ強固な内固定が求められる. またシャント側では 術後の固定も制限される.すなわち侵襲が大きかつた り, 厳密な外固定を必要とする治療法は選択できない.

以上を踏まえ治療法の選択すると, 骨障害として骨 脆弱性があるためスクリューを用いた固定性は期待し 難い. 全身的問題として易出血性と易感染性があるた め, 鋼線締結法や Ender 釘, inter rocking nail な ぞの手術法は侵襲が大きく行い難い.これらの理由に よりやむなく保存治療を選択することになるのだが, 除痛は不十分であり, 透析治療を受けているため,
ADL もかなり制限される. 長期の安静を余儀なくさ れるため, 痴呆や肺炎の合併なども危惧される. また シャント側では体幹固定は維持できず牽引療法も非常 に困難であり理想的な治療とは言い難い.もともと骨 化障害があることからも何らかの内固定が必要だと考 える.

上腕骨頚部骨折に対する観血的療法は種々の方法が 報告されているが, 固定力, 手術手技の難易度や手術 に伴う侵襲を考えると一長一短である．手術侵襲の少 ない方法の一つである Kirschner 鋼線を用いた方法 は, 高齢者においても良好な結果が報告されているが 著明な骨粗鬆症を有する症例では固定性に難があり， 術後に鋼線が末梢へ滑脱し，場合によっては上腕骨骨 頭の転位を生じ，肩関節の可動域が不良になることも ある. 小川ら，宮川ら ${ }^{56)}$, は重度の骨粗鬆症を有する 症例では適応を慎重にすべきであると述べている．低 侵襲かつ必要十分な固定性を得られる手術療法が理想 であるが我々の彎曲鋼線髄内固定法はこれらの条件を 満たすことができた. また全身麻酔に比較して伝達麻 酔は全身への影響を減らすことができるという点で有 用である。しかし痴呆を有する症例では伝達麻酔は放 散痛の有無の確認が困難なため不向きである7).この ような症例では, 局所麻酔法は完全な除痛は難しいが, 十分手術に耐えられる方法であった.

彎曲 Kirschner 鋼線による固定術の長所は，手術 に伴う侵襲が少ない割には固定性が良好である, 骨折 部の展開が不要であるため仮骨形成が早い, 状態によっ ては局所麻酔でも手術は可能である, などの点が挙げ られる。

また今回，成績向上のため，従来の方法にいくつか の工夫を加えた. K-wire の刺入を遠位の骨孔より行 うことで刺入部の縦割れの予防に努めた。 また骨脆弱 性に対しては Kirschner 鋼線の彎曲を強め，また本 数を原則として 4 本挿入することで対応した。 また骨 化障害に対しては術後 X 線により仮骨を確認してか ら自動運動を開始することで, 変形治癒・偽関節発生 の予防に努めた。

結 語

(1)血液透析患者の上腕骨頚部骨折 6 例に対し彎曲 Kirschner 鋼線髄内固定法を行つた.

(2)従来の方法に改良を加え，良好な術後成績を得る 
ことができた.

(3)侵襲が少なく，手技も容易なため，透析患者のよ うなリスクの高い症例に対しても安全かつ有効な治療 法である.

\section{参 考 文 献}

1）相澤利武ほか：上腕骨近位端骨折に対する保存療法の 適応之限界. MB Orthop, 10(7)：19-29, 1997.

2）井原成男ほか：上腕骨近位端骨折に対する彎曲キルシュ ナ一鋼線䯣内固定法. 整外と災外, $47: 708-711,1998$.

3）市村和徳ほか：高齢者上腕骨近位部骨折の予後. 骨折, $23: 161-163,2001$.

4）松林孝王：大腿骨頝部骨折患者の生命予後の影響を及
ぼす因子．整形外科 MOOK, $62: 65-69,1991$.

5）宮沢知修：上腕骨外科頝骨折に対する Kirschner 鋼線 髄内固定法の治療経験。関節外科, $17: 1205-1208,1998$ 。

6）小川清久ほか：上腕骨近位端骨折に対する逆行性 Kirschner 鋼線䯣内固定。整外之災外，44：359-364, 2001.

7）多淵八千代：整形外科透析症例の術前後（術中を含む） の管理．関節外科, 16(5)：585-591，1997.

8）武尾良己：長期透析患者の手術療法の問題点. 関節外 科, 9(7):883-890, 1990.

9）Winnie, A. P. (川島康男ほか) ：腕神経叢ブロックの 鎖骨下（subclavian）血管周囲法. 腕神経叢ブロック (第1 版)，145-166。真興交易，1988. 